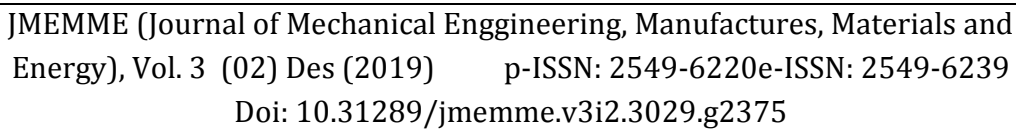

JMEMME (Journal of Mechanical Engineering, Manufactures, Materials and Energy)

\title{
ANALISA PENGARUH WAKTU DAN TURBULENSI ASAP PADA MESIN PENGERING IKAN LELE
}

\author{
Darianto*, Amrinsyah, Hiras T.S. Sitohang \\ Program Studi Teknik Mesin, Universitas Medan Area \\ Diterima: 30-10-2019 ; Disetujui: 24-12-2019 ; Diterbitkan: 30-12-2019 \\ *Corresponding author: darianto0226@gmail.com
}

\begin{abstract}
Abstrak
Indonesia kaya akan sumber hayati, salah satunya adalah gudang sumber penghasil protein hewani khususnya ikan. Pengasapan adalah salah satunya cara pengawetan ikan yang dapat dilakukan dengan peralatan yang sederhana dan mudah didapat serta harganya murah.Tujuan penelitian ini adalah mendapatkan waktu ideal utuk proses pengasapan ikan dengan suhu $60^{\circ} \mathrm{C}$ sampai dngan $70^{\circ} \mathrm{C}$ waktu pengasapan 8 jam.Berat ikan yang diasapi dalam penelitian ini adalah 500 kg.Dan bahan bakar yang digunakan untuk pengasapan ikan adalah kayu jati.Dimana kayu ini dipilih sebagai bahan bakar karena sifatnya yang keras, sehingga dapat menghasilkan asap yang tebal dan mengeluarkan aroma yang cukup baik untuk ikan asap.Berdasarkan hasil pengujian dan perhitungan serta analisa data dapat diperoleh bahwa waktu pengasapan ideal yang dibutuhkan untuk mengasapi atau mengeringkan ikan lele sale adalah 8 jam.Dimana dengan menggunakan waktu 8 jam dapat menurunkan kadar air pada ikan sebesar dengan 70 \%.Penurunan kadar air sebesar $70 \%$ dipengaruhi oleh waktu pengasapan dan pemilihan bahan bakar yang bersifat keras dan pengkontrolan suhu pengasapan yang dilakukan secara rutin.
\end{abstract}

Kata Kunci : Kayu keras, waktu pengasapan deal, kadar air

\section{ANALYSIS OF THE TURBULENCE OF SMOKE ON CATFISH DRYES}

\begin{abstract}
Indonesia is rich in biological resources, one of which is a warehouse source of animal protein producer, especially fish. Fogging is one way of preserving fish that can be done with equipment that is simple and easy to obtain and the price is cheap. The purpose of this research is to get ideal time for the process of fuming fish with temperature 600C to 700C fog time 8 hours. The fish weight fogged in this study in $500 \mathrm{~kg}$. And the fuel used for fumigation is Jati wood. Where this wood is selected as fuel because of its hardness, so it can produce a thick fog and produce a pretty good scent for fogged fish.Based on the test results and calculations and data analysis can be obtained that the ideal curing time needed to bloat or dry the catfish sale is 8 hours. Where by using time 8 hours can decrease water content in fish equal to 70\% is influenced by curing time and hard fuel selection and regular temperature control of fumigation.
\end{abstract}

Keywords: Hardwood, Time fogging deal, Moisture content

How to Cite: Darianto, 2019, Analisa Pengaruh Waktu dan Turbulensi Asap Pada Mesin Pengering Ikan Lele, JMEMME (Journal of Mechanical Enggineering, Manufactures, Materials and Energy), 3(02): 130-142 


\section{PENDAHULUAN}

Indonesia kaya akan sumber hayati, salah satunya adalah gudang sumber penghasil protein hewani khususnya ikan. Negara kita juga kaya akan keanekaragaman perikanan baik ikan laut maupun ikan tawar. Ikan memang mengandung komposisi gizi yang ideal.Ikan mengandung 18 persen protein terdiri atas asam amino esensial yang tidak rusak pada waktu pemasakan. Kandungan lemaknya 1-20 persen lemak yang mudah dicerna serta langsung dapat digunakan oleh jaringan tubuh. Kandungan lemaknya sebagian besar adalah asam lemak tak jenuhyang dapat dibutuhkan untuk pertumbuhan dan dapat menurunkan kolesterol darah.

Pengasapan adalah salah satu cara pengawetan ikan yang dapat dilakukan dengan peralatan yang sederhana dan mudah didapat serta harganya murah. Ikan yang diolah dengan cara pengasapan dapat bertahan lebih lama disebabkan beberapa factor, diantaranya berkurangnya kadar air ikan dibawah 40 persen, adanya senyawa-senyawa asam kayu yang dapat menghambat pertumbuhan mikroorganisme pembusuk dan terjadinya koagulasi protein pada permukaan ikan yang mengakibatkan jaringan pengikat menjadi lebih kuat dan kompak sehingga tahan terhadap serangan mikroorganisme. Senyawa- senyawa antimikroba yang terdapaat dalam asap misalnya berbagai macam aldehida, alcohol, asam dan sebagainya. Pengasapan juga dapat memperbaiki penampakan ikan karena ikan menjadi terlihat berminyak atau mengkilat.
Sektor perikanan sebagai salah satu pendukung sektor ekonomi memiliki peran dalam pembangunan ekonomi nasional, yaitu memberikan nilai tambah dan mempunyai nilai strategis, serta dapat memberikan manfaat financial maupun ekonomi, khususnya dalam penyediaan bahan pangan protein, perolehan devisa, dan penyediaan lapangan kerja. Sejauh ini pembangunan perikanan yang dilakukan telah menujukkan hasil yang nyata dan positif terhadap pembangunan nasional.Hal ini terlihat dari sumbangan produk domestik bruto (PDB) sektor perikanan terhadap PDB nasional yang terus meningkat. Kontribusi sektor perikanan dan kelautan terhadap PDB nasional yang mencapai sekitar 12,4\%. Bahkan industri perikanan menyerap lebih dari 16 juta tenaga kerja secara langsung (Dahuri, 2004).Salah satu metode pengawetan ikan adalah dengan metode pengasapan selain disimpan dalam suhu rendah, diasinkan atau dipresto.Dengan metode pengawetan ini daging ikan yang biasanya membusuk dalam waktu singkat dapat disimpan dalam suhu kamar untuk jangka waktu berbulanbulan, walaupun biasanya harus ditutup rapat. Ikan sebagai bahan makanan mengandung protein tinggi dan mengandung asam amino esensial yang diperlukan oleh tubuh, disamping itu nilai biologisnya mencapai 90\%, dengan jaringan pengikat sedikit sehingga mudah dicerna oleh konsumen sebagaimana yang disampaikan oleh Adawyah, 2007. Dengan demikian prinsip pembuatan olahan ikan asap merupakan salah satu cara untuk memperpanjang daya simpan dan 
Darianto, Analisa Pengaruh Waktu dan Turbulensi Asap Pada Mesin Pengering ...

menambah nilai jual dari produk tersebut.

Selain keuntungan-keuntungan tersebut, pengasapan ikan mempunyai beberapa kelemahan karena tekstur ikan berubah menjadi keras terutama jika pengasapan dilakukan pada suhu rendah dalam waktu lama dan diperlukan waktu lama untuk melakukan pengasapan ikan yang sempurna. Sedangkan yang teksturnya keras diperlukan proses dehidrasi (pembasahan kembali) sebelum ikan dapat dikonsumsi.

Pertumbuhan jamur pada ikan asap menyebabkam terjadinya perubahan bau menjadi tengik dan perubahan tekstur.Pengolahan ikan dengan menggunakan asap untuk komsumsi manusia sudah dikenal sejak zaman dahulu, tetapi cara pengolahannya sederhana, biaya murah dan mudah dikerjakan. Dibandingkan dengan ikan asin, ikan asap lebih unggul baik dari segi rasa ( kelejatan ), gizi dan juga harga jualnya. Meskipun mempunyai beberapa ke unggulaan,di Indonesia maupun Asia ikan asap kalah penjualan dari pada ikan asin.

Karena ikan asap harus diolah lagi dengan menambah bumbu-bumbu lainnya. Dan juga ada anggapan ikan asap dapat menimbulkan penyakit kanker atau bersifat kansirgernik. Alasan ini karena ikan asap mengandung senyawa yang dicurigai menjadi penyebab kanker, yaitu Pilicylic Aromatic Hydrocarbon (PAH).

Senyawa PAH yang ditakuti ternyata ditemukan juga dimakanan olahan lain seperti : roti, biskuat, kopi, minyak kedelai, sate,ikan bakar, ikan kaleng, dan bahkan pada ikan segar termasuk kepiting, udang, lobster. Dibandingkan dengan olahan lain, kandungan PAH pada ikan asap masih tergolong rendah. Sementara senyawa vitamin A dan anti oksida mampu menghambat daya karsinogenik PAH. Dari penelitian-penelitian yang dilakukan, ikan asap,juga maakanan asap lainnya bukanlah penyebab karsinogenik yang membahayakan manusia yang mengomsusinya.Ikan asap ini umunya cukup popular dan digemari di daerah Sumatera. Kalimantan, dan Sulawesi serta dijawa. Jenis ikan yang banyak di gemari setelah diasap adalah ikan bandeng, cakalang,tongkol,dan tuna. Harga jualnyapun tinggi.

Dengan meningkatnya tingkat pendidikan, kesejahteraan, dan kesadaran akan hidup sehat, pola komsumsipun ikut bergeser dan peluang ikan asap untuk digemari makin terbuka. Disisi lain, semakin berkembangnya alat tangkap ikan, hasil tangkapanpun terus meningkat sehingga pemanfaatan untuk ikan asappun akan meningkat. Hal ini menjadikan ikan asap kian menarik untuk digeluti dan dapat dijadikan usaha yang menguntungkan.

Produk hasil pengasapan ( ikan asap ) merupakan produk yang disukai oleh konsumen, namun beberapa ikan asap memiliki daya awet yang tidak tahan lama. Daya awet dan mutu ikan asap dapat dipertahankan dengan melakukan penyimpanan yang baik dan benar.Salah satu teknik penyimpanan yang bias dilakukan terhadap produk ikan asap yaitu penyimpanan dingin atau penyimpanan suhu rendah.

Ikan salah satu komoditas ungglan perikanan budidaya air tawar. Produksi 
nominal ikan lele dari tahun 2010 sampai dengan tahun 2014 mengalami kenaikan dari 242,811 ton menjadi 463,221 ton. Nilai rata-rata produksi lele mencapai 37,49\% ( Ditjen Budidaya KKP 2014 ). Perkembangan yang pesat dan tingginya produksi budidaya ikan lele diduga karena ikan lele dapat dibudidayakan di lahan dan sumber air yang terbatas dengan padat tebar tinggi, teknologi budidaya relative mudah dan dikuasai oleh masyarakat, pemasarannya relative mudah serta modal usaha budidaya lele yang diburuhkan relative rendah. Saat ini teknologi pembesaran lele semakin berkembang, diantaranya adalah teknologi kolam terpal dan permanen. Teknologi ini banyak digunakan baik masyarakat pribadi dan kelompok pumbudidaya ikan (Pokdakan) sehingga terkadang membuat harga lele segar tidak stabil di pasaran; rata-rata harga perkilogramnya hanya Rp. 13.000 - Rp 15.000 [].

Ikan lele mempunyai protein tinggi 17,7-26,7\% dan lemaknya berkisar 0,95 sampai dengan $11,5 \%$ ( Nurimala et al 2009 ). Rosa et al. (2007) melaporkan bahwa ikan lele dapat dikelompokkan kedalam bahan pangan berprotein sedang dengan lemak rendah.Rohimah et al. (2014) menyebutkan bahwa kandungan komponen gizi ikan lele mudah dicerna dan diserap oleh tubuh manusia baik pada anak-anak dewasa, dan orang tua.

Salah satu upaya untuk meningkatkan pendapatan budidaya ikan lele adalah dengan melakukan diversifikasi olahan ikan lele asap. Melalui upaya ini harga ikan lele asap mencapai Rp.120.000 per kilogram (BPS
2013). Teknologi pengolahan ikan asap panas saat ini telah banyak dilakukan berbagai daerah dan salah satunya Provinsi Sumatera Utara.

\section{METODE PENELITIAN}

Prosedur Pengasapan Ikan Lele adalah sebagai berikut:

a. Proses Penggaraman Ikan Lele.

Tahap awal sebelum melakukan proses pengasapan ikan lele yaitu, menyediakan bahan baku utama yaitu ikan lele. Setelah ikan lele tersedia selanjutnya ikan lele dibelah dengan alat potong.Setelah ikan terbelah maka, isi perut dan insang ikan di keluarkan.Selanjutnya, ikan di masukkan kedalam drum yang telah berisi air yang sudah di garami. Dalam satu dr um berisi air dimasukkan garam sebanyak 3 bungkus dengan ukuran garam perbungkus 500 gram. Setelah ikan dimasukkan didalam drum, ikan dibiarkan berada dalam drum selama 30 menit. Proses penggaraman ikan lele diperlihatkan pada gambar 1 .

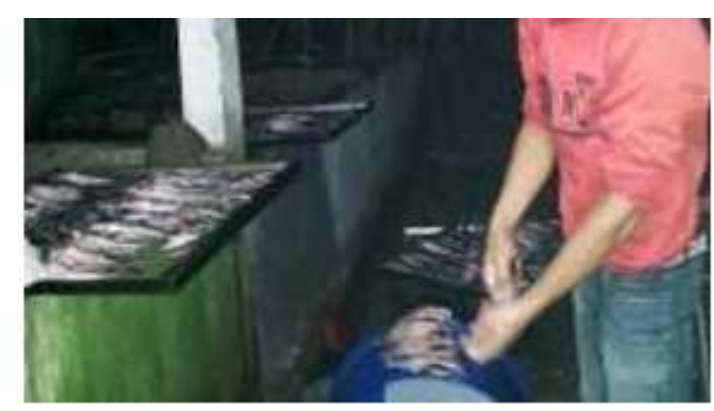

Gambar 1. Proses Penggaraman

b. Proses Pengasapan Tahap Awal

Setelah penggaraman selesai selanjutnya, ikan di bilas kemudian ditiriskan diatas rak dengan tujuan sebelum masuk kedalam dapur pengasapan kadar air yang berada dalam 
Darianto, Analisa Pengaruh Waktu dan Turbulensi Asap Pada Mesin Pengering ...

ikan berkurang. Dan ikan ditiriskan selama 15 menit.

Setelah ikan ditiriskan selama 15 menit, selanjutnya ikan dimasukkan kedalam lemari. Untuk mendapatkan aliran asap yang merata jarak antara ikan di rak paling bawah atau yang paling dekat dengan sumber asap tidak terlalu rapat sehingga aliran asap dari bawah bisa sampai ke rak paling atas. Sehingga turbulensi pengasapan merata. Dalam pemanasan tahap awal, suhu lemari asap sekitar $40-60^{\circ} \mathrm{C}$ selama 3 jam. Dalam pemanasan awal posisi bagian daging (potongan) menghadap kebawah dengan tujuan penurunan kadar air dalam daging lebih cepat. Setelah pemanasan awal berlangsung selama 15 menit ikan ditarik keluar dari lemari pengasapan. Setelah ikan ditarik keluar posisi ikan dibalik, dimana bagian kulit ikan menghadap sumber asap dan setelah posisi ikan diganti ikan dimasukkan kembali kedalam lemari pengasapan.Dan tidak posisi ikan saja yang di ganti, posisi rak juga diganti dimana rak pertama diganti menjadi rak nomor sepuluh dan begitu juga seterusnya dengan rak yang lain. Hal ini dilakukan untuk menghindari ikan terlalu cepat kering tetapi proses pengeringan tidak merata.Pengasapan dilakukan dan diteruskan sampai permukaan ikan berwarna kekuningan atau coklat kekuningan, dengan keadaan ini ikan dianggap telah cukup untuk mencegah terjadinya pelendiran.

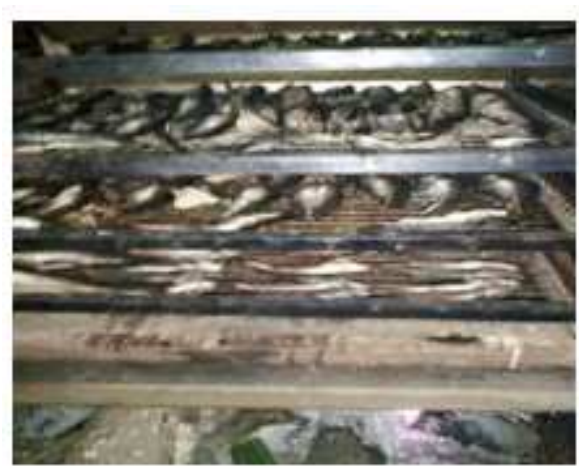

Gambar2. Proses pengasapan tahap awal

c. Pengasapan tahap kedua

Pengasapan tahap kedua dilakukan pada suhu $65-70{ }^{\circ} \mathrm{C}$ selama 2 jam.Pada pengasapan ini diperlukan ketelitian karena suhu yang tinggi sangat mempengaruhi tekstur ikan.Dimana, dengan suhu tinggi ikan bisa saja mengalami kekeringan dimana bisa mengakibatkan tekstur ikan terlalu rapuh. Dimana jika tekstur ikan terlalu rapuh ikan akan semakin keras dan protein yang ada dalam ikan bisa berkurang. Selain itu, ikan juga akan susah dipasarkan karena tekstur ikan terlalu keras sehingga kurang diminati masyarakat. Dan sebaliknya jika suhu pengasapan tidak sesuai lamanya dengan waktu pengasapan maka ikan tidak kering. Jika hal ini terjadi maka ikan akan lebih mudah terserang jamur. Hasil proses pengasapan tahap kedua diperlihatkan pada gambar 3 . 


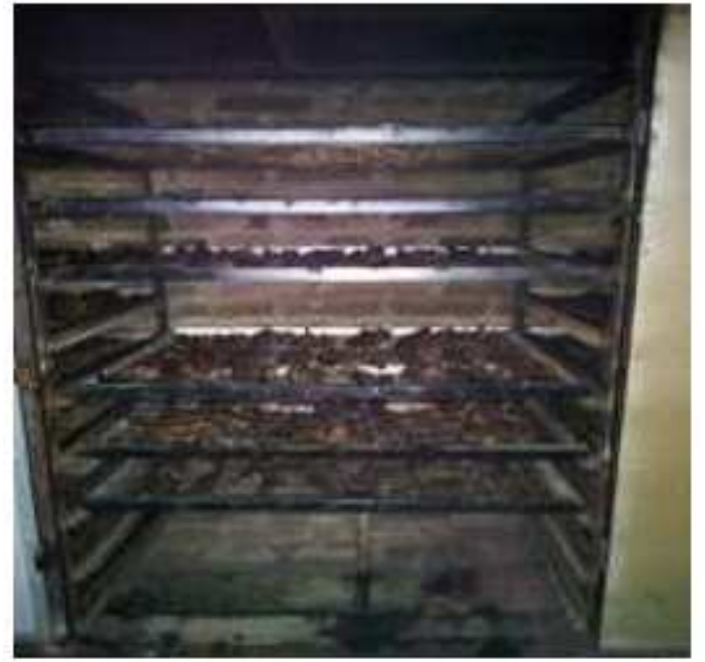

Gambar 3. Hasil pengasapan tahap kedua

\section{Keberhasilan Proses Pengasapan}

Tingkat keberhasilan proses pengasapan ikan tergantung pada empat factor utama (selain bahan baku) yang saling berkaitan, yaitu: mutu dan volume asap, suhu dan kelembapan, ruang pengasapan, waktu pengasapan, sirkulasi udara dalam ruang pengasapan, dan pengaruh turbulensi asap pada hasil pengasapan ikan lele.

\section{Mutu dan Volume Asap}

Mutu dan volume asap yang dihasilkan tergantung pada jenis kayu yang digunakan dalam proses pengasapan. Dalam penelitian ini digunakan kayu jati. Kayu ini gunakan karena untuk mendapatkan mutu dan volume asap yang sesuai yang diharapkan, sebaiknya digunakan jenis kayu yang keras (non-resinous). Selain itu kayu bakau, rasa mala, dan tempurung kelapa bisa juga digunakan sebagai bahan bakar. Asap yang dihasilkan dari pembakaran kayu keras akan berbeda komposisinya dengan asap yang dihasilkan dari pembakaran kayu lunak. Pada umumnya kayu keras akan menghasilkan aroma yang lebih unggul, lebih kaya kandungan aromatic dan lebih banyak mengandung senyawa asam dibandingkan kayu lunak. Pada penggunaan kayu keras, asap yang dihasilkan gumpalan asap yang tebal dan tidak terlalu menyebar.Bila menggunakan kayu lunak (resinous), asap yang dihasilkan banyak mengandung senyawa yang dapat menimbulkan hal dan bau yang tidak di inginkan. Dengan kata lain jenis kayu yang digunakan sebagai sumber asap sebaiknya memenuhi tiga syarat, yaitu keras, tidak mudah/cepat terbakar, dapat menimbulkan asap dalam jumlah yang besar dan dalam waktu yang lama. Dalam penelitian ini bahan bakar yang digunakan bahan bakar padat alami yaitu bahan bakar kayu (wood).

\section{Suhu dan Kelembapan Ruang Pengasapan}

Kondisi ruang pengasapan juga sangat menentukan mutu ikan asap. Ruangan pengasapan ikan adalah ruangan yang memiliki suhu dan kelembapan udara cukup rendah. Banyaknya uap air yang diserap oleh udara tergantung suhunya, jadi bila udara cukup dingin $30^{\circ} \mathrm{C}$ dipanasi maka kapasitas pengeringan akan lebih tinggi. Dalam keadaan lembab, uap jenuh yang telah panas tidak dapat dipanasi lagi secara tepat untuk mengurangi kandungan uap airnya dan oleh karena itu, kapasitas menurun. Jika suhu ruang pengasapan cukup rendah, asap yang dihasilkan dari proses pengasapan di udara terbuka (bersuhu relative tinggi). Dengan demikian, volume asap yang dapat melekat pada tubuh ikan menjadi lebih banyak dan merata. Apabila proses 
Darianto, Analisa Pengaruh Waktu dan Turbulensi Asap Pada Mesin Pengering ...

pengasapan ikan berlangsung dalam ruangan bersuhu tinggi, permukaan kulit atau tubuh bagian luar akan menjadi cepat kering atau mengeras (dapat menghalangi proses penguapan cairan yang terdapat pada bagian tubuh yang lebih dalam), sehingga proses pembusukan masih mungkin terjadi pada tubuh ikan bagian dalam.

\section{Waktu Pengasapan}

Menurut Rasco (2009), metode pengasapan panas pada ikan memerlukan 2 proses berurutan yaitu pengasapan diikuti oleh pemasakan. Lama waktu pengasapan tergantung pada flavor dan kelembapan yang di inginkan. Lama waktu pengasapan sangat berpengaruh terhadap kualitas ikan. Dan dari lamanya waktu pengasapan akan menghasilkan warna ikan yang kecoklatan dan kehitaman. Dalam penelitian ini dibutuhkan waktu pengasapan dari tahap awal sampai akhir selam 8 jam.Dan dari hasil pengamatan ikan berwarna kecoklatan, tentu warna ini dihasilkan dari jenis kayu yang digunakan selama pengasapan.

Sirkulasi Udara Dalam Ruang Pengasapan

Adanya sirkulasi udara yang baik di dalam ruang pengasapan menjamin mutu ikan asap yang lebih sempurna. Sirkulasi udara yang baik akan menjaga suhu dan kelembapan ruang pengasapan tetap konstan selama proses pengasapan berlangsung. Selain itu, aliran asap akan berjalan lancar dan kontiniu, sehingga partikel asap yang menempel pada tubuh ikan akan menjadi lebih banyak dan merata. Jadi pada tahap pengasapan, kecepatan penguapan air tergantung pada kapasitas pengering udara dan asap juga kecepatan pengaliran asap. Pada tahap kedua, di mana permukaan ikan sudah agak kering, suhu ikan akan mendekati suhu udara dan asap. Kecepatan pengeringan akan menjadi lambat karena air harus merembes dahulu dari lapisan dalam daging ikan, bila pengeringan mula-mula dilakukan pada suhu yang terlalu tinggi dan terlalu cepat, maka permukaan ikan akan menjadi keras dan akan menhambat penguapan air selanjutnya dari lapisan dalam, sehingga kemungkinan daging ikan bagian dalam tidak mengalami efek pengeringan.

\section{Pengaruh Turbulensi Asap Pada Hasil} Pengasapan Ikan Lele

Aliran turbulen adalah aliran fluida yang partikel-partikelnya bergerak secara acak dan tidak stabil dengan kecepatan berfluktuasi yang saling interaksi.Akibat dari hal tersebut garis alir antar partikel fluidanya saling berpotongan.Oleh Osborne Reynold digambarkan sebagai bentuk yang tidak stabil yang bercampur dalam waktu yang cepat yang selanjutnya memecah dan menjadi takterlihat.Pada arus turbulen, massa air bergerak keatas, kebawah, dan secara lateral berhubungan dengan arus yang umum, memindahkan massa dan momentum.Dengan gerakan tidak beraturan seperti itu, massa atau gumpalan fluida akan mempunyai percepatan menyimpang yang hanya sedikit persenrtasinya dari kecepatan rata-rata, meskipun begitu arus turbulen bersifat menentukan arus, sebab turbulen menjaga partikel-partikel 
dalam suspense, secara konstan, seperti clay dan slit pada sungai dan pasir pada sungai dan pada pasir pada arus turbidit, atau secara berangsur seperti pada kebanyakan butir pasir disungai, pantai dan bukit pasir.

Turbulensi asap pada lemari pengasapan sangat berpengaruh pada hasil dan lamanya waktu pengasapan. Pada penelitian ini turbulensi asap yang terjadi dalam lemari pengasapan sangat berpengaruh positif karena arah asap yang ada didalam lemari pengasapan sifatnya bolak-balik. Jadi, hal ini sangat menguntungkan pada ikan yang berada didalam lemari pengasapan. Dimana ikan akan terkena asap dengan waktu yang lama. Berbeda halnya jika menggunakan aliran laminar atau searah.Asap lebih banyak terbuang ke udara bebas sehingga waktu yang dibutuhkan untuk pengasapan lebih banyak. Hal ini juga sangat memepengaruhi juga dengan bahan bakar, dimana bahan akan lebih banyak habis.

\section{HASIL DAN PEMBAHASAN}

Perhitungan volume lemari pengasapan ikan

Untuk mengetuhui volume lemari pengasapan dapat diketahui dengan rumus, $\mathrm{V}=\mathrm{P} \times \mathrm{l} \times \mathrm{t}$. Dimana $\mathrm{P}=$ Panjang lemari pengasapan, $\mathrm{l}=$ Lebar lemari pengasapan, dan $t=$ Tinggi lemari pengasapan.

$$
\begin{aligned}
& V=4 \mathrm{~m} \times 0,8 \mathrm{~m} \times 1,20 \mathrm{~m} \\
& V=3,84 \mathrm{~m}^{3}
\end{aligned}
$$

Selanjutnya Volume lemari pengasapan ikan dibagi dengan jumlah ikan yang akan diasapi dalam lemari pengasapan. Dimana dalam penelitian ini jumlah berat ikan yang di asapi adalah: $500 \mathrm{~kg}$. Dimana rata - rata $1 \mathrm{~kg}$ ikan berjumlah 10 ekor ikan. Maka $500 \mathrm{~kg}$ ikan $=5000$ ekor. Sehingga Volume dibagi dengan jumlah ikan.

$\mathrm{V}=3,84 \mathrm{~m}^{3} / 5000$ ekor $=0,000768$ $\mathrm{m}^{3} /$ ekor

Pengujian nilai kalor pada komposisi kimia kayu

Pengujian nilai kalor bahan bakar kayu yang digunakan selama proses pengasapan.Pada penelitian ini kayu yang digunakan sebagai bahan bakar adalah kayu yang sifatnya keras. Bahan bakar padat yang sebagian besar terdiri dari Karbon Hidrogen dan Oksigen, pembakarannya berlangsung sebagai berikut.

Mula-mula bahan bakar tersebut akan membentuk gas-gas atau yang bisa disebut mengegas (on-gassing), pada waktu berlangsung destilasi kering, dan gas-gas tersebut akan terurai lebih lanjut menjadi $\mathrm{CO}$ dan $\mathrm{H}_{2}$ (water gas) dan akan terbakar. Carbon adalah unsur-unsur yang dapat terbakar dari susunan hidro carbon. Oksidasi carbon agak lambat dan lebih sulit bila dibandingkan dengan unsur hydrogen dan sulfur. Walaupun carbon mempunyai suhu pembakaran yang lebih rendah dari zat cair, carbon adalah zat padat dengan temperatur tinggi dan pembakarannya relative lambat. Sebagai konsekuensinya pada beberapa proses pembakaran yang teoritisi, ini akan disampaikan bahwa kedua unsure sulfur dan hydrogen terbakar dengan sempurna sebelum carbon terbakar. Selanjutnya ini akan 
Darianto, Analisa Pengaruh Waktu dan Turbulensi Asap Pada Mesin Pengering ...

diasumsikan bahwa semua carbon akan teroksidasi menjadi karbon monoksida (CO) sebelum setiap carbon berubah menjadi carbon dioksida $\left(\mathrm{CO}_{2}\right)$.Reaksi kimianya sebagai berikut:

$$
\begin{array}{r}
48,5 \mathrm{C}+\mathrm{O} 2 \rightarrow 48,5 \mathrm{CO}+\mathrm{Qc} . \mathrm{co}=121250 \\
\mathrm{~kJ} / \mathrm{kg} \mathrm{mol}
\end{array}
$$

Jumlah kalori yang digunakan pada bahan bakar pengasapan ialah nilai kalori bahan bakar kayu ( Wood ) = 2500 $\mathrm{x}$ jumlah bahan bakar yang digunakan selama proses pengasapan.

Kalori $=2500 \mathrm{Kcal} / \mathrm{kg} \times 150 \mathrm{~kg}=$ 375.000 Kcal.

Maka, jumlah kalori yang terdapat dalam bahan bakar selama pengasapan adalah 375.000 Kcal.

Pembakaran Carbon :

$2 \mathrm{CO}+\mathrm{O}_{2} \rightarrow 2 \mathrm{CO}_{2}+2$ Qco-co

$\mathrm{Qco}-\mathrm{co} 2=375.000 \mathrm{~kJ} / \mathrm{kg} \mathrm{mol} \mathrm{CO}$

Oksigen yang dibutuhkan :

$\mathrm{O}_{2}=\stackrel{375.000 \mathrm{~s} 32}{=} \underset{24,02}{=} \frac{12000000}{24,02}=4 \mathrm{yb} 6 /, / / \mathrm{kg}$

unsur-unsur yang dapat terbakar dari Hidrocarbon mempunyai temperature pembakaran yang tertinggi yaitu : $582{ }^{\circ} \mathrm{C}$. Tetapi selama terbentuk gas hydrogen beroksidasi menjadi air seperti diperlihatkan dalam persamaan reaksi kimia di bawah ini :

$2 \mathrm{H}+\mathrm{O}_{2}+\mathrm{H}_{2} \mathrm{O}+2 \mathrm{OH}=7.500 .000 \mathrm{kj} / \mathrm{kg}$ $\mathrm{mol} \mathrm{H}_{2}$

Jadi, kebutuhan oksigen untuk pembakaran (pengasapan) 5000 ekor ikan adalah:

$\mathrm{O}_{2}=\frac{5000 \mathrm{~s} 32}{4,032 \mathrm{~s}}=39682,54 \mathrm{O}_{2} / \mathrm{kg}$
Nilai Panas (Heating Value)

Nilai panas (kalor) kita defenisikan sebagai energi panas yang dilepaskan pada waktu terjadi oksidasi unsur- unsur kimia yang terdapat dalam bahan bakar kayu. Nilai panas atau nilai kalor dari unsur-unsur carbon, Hidrogen dan sulfur seperti disebutkan dalam persamaaan kimia di atas adalah sebagai berikut:

Nilai panas carbon:

$$
\begin{aligned}
& \mathrm{Q}_{\mathrm{c}-\mathrm{co}}=121250 \mathrm{~kJ} / \mathrm{kg} \cdot \mathrm{mol} \mathrm{C} \\
& =\frac{121250}{12,01} \\
& =10104,17 \mathrm{~kJ} / \mathrm{kg} \mathrm{C} \\
& =10104,17 \times 0,2388 \\
& =3314,17 \mathrm{kkal} . \mathrm{mol} \mathrm{CO}
\end{aligned}
$$

Dalam hal Nilai Panas (kalor) Carbon tidak ada nilai tertinggi dan terendah, karena tidak ada kehilangan energy panas selama terjadinya reaksi kimia.

Nilai panas Hidrogen:

$\mathrm{Q}_{\mathrm{h}}=2250000 \mathrm{~kJ} / \mathrm{kg} \cdot \mathrm{mol} \mathrm{H} \mathrm{H}_{2}$ $=\frac{2250000}{2,016}$

$=1116071,43 \mathrm{kj} / \mathrm{kgH}_{2}$

$=266556,35 \mathrm{kkal} / \mathrm{kg} \mathrm{H}_{2}$

Dalam peristiwa oksidasi $\mathrm{H}_{2}$ terbentuk $\mathrm{H}_{2} \mathrm{O}$ (air) yang dalam tempo relatif singkat berubah menjadi uap air $\left(\mathrm{H}_{2} \mathrm{O}\right)$. Dalam peristiwa perubahan fasa ini dibutuhkan panas laten (Laten Heat) yang besarnya tergantung pada keadaan sekelilingnya (tekanan dan suhu). Dalam lemari pengasapan diestimasikan tekanan sama dengan satu atmosfir mutlak, jadi panas laten air:

$\mathrm{L} \mathrm{H}_{2} \mathrm{O}=539,8 \mathrm{kkal} / \mathrm{kg}$ 
Nilai Panas $\mathrm{H}_{2}$ sebelum dikurangi panas pembentuk uap disebut N. Nilai Panas kotor (Tertinggi) atau Gross (Higher) Heating Value.

Jadi:

$\mathrm{HHVh}=3197,53 \mathrm{kkal} / \mathrm{kg} \mathrm{H}$

$\mathrm{LHVh}=266556,35 \mathrm{kkal} / \mathrm{kg} \mathrm{H} 2$

Perbedaan antara HHV dan LHV merupakan panas laten dari sejumlah uap air yang terjadi dari hasil pembakaran bahan bakar bersangkutan bila pembakaran memakai udara kering.

\section{Pengujian Produktivitas Asap}

Berat bahan bakar yang berbeda sangat pengaruh besar dengan kecepatan pembakaran, dimana bahan bakar yang mempunyai berat $5 \mathrm{~kg}$ sangat mudah terbakar dan menghasilkan gumpalan asap yang kurang sempurna.Dan biasanya bahan bakar yang mempunyai berat kurang lebih $5 \mathrm{~kg}$ digunakan di awal pengasapan. Sedangkan bahan bakar yang mempunyai berat $20 \mathrm{~kg}$ lebih bagus dari ukuran yang sebelumnya dimana ukuran yang $20 \mathrm{~kg}$ lebih lama terbakar dan menghasilkan gumpalan asap yang lebih tebal.Dan bahan bakar yang ukurannya $20 \mathrm{~kg}$ digunakan dipertengahan pengasapan. Lebih bagusnya yaitu dengan menggunakan bahan bakar kayu yang mempunyai berat $30 \mathrm{~kg}$. Dimana, bahan bakar yang mempunyai ukuran lebih berat akan menghasilkan gumpalan asap yang lebih tebal dan proses pembakarannya lebih lama. Dan biasanya ukuran bahan bakar yang lebih berat digunakan setelah api sudah menyala sekitar kurang lebih 2 jam. Jumlah bahan bakar yang digunakan selama pengasapan $\pm 150 \mathrm{~kg}$.
Tabel 1. Jumlah bahan bakar yang digunakan

\begin{tabular}{c|c}
\hline BERATBAHAN BAKAR $(\mathrm{Kg})$ & PROSES AKHIR \\
\hline 30 & Finishing pengasapan \\
\hline 120 & Proses pengasapan \\
\hline
\end{tabular}

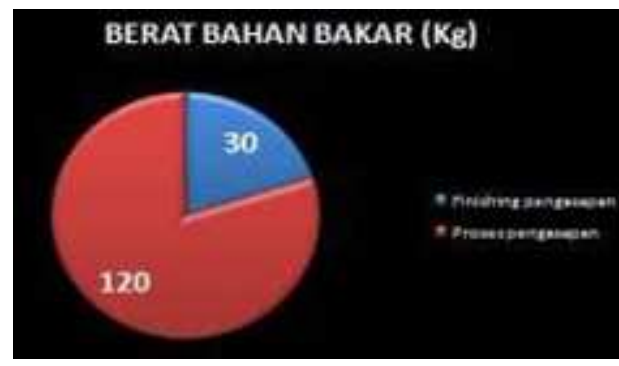

Gambar 4. Penggunaan bahan bakar selama proses pengasapan

Dari grafik pada gambar 4 menunjukkan bahwa bahan bakar yang digunakan sebelum finishing pengasapan yaitu sebanyak $120 \mathrm{~kg}$. Finishing pengasapan menggunakan bahan bakar sebanyak $30 \mathrm{~kg}$. Dalam penelitian ini banyaknya bahan bakar yang digunakan selama proses pengasapan tidak sama dengan jumlah bahan bakar yang digunakan untuk finishing karena untuk finishing suhu pengasapan tidak boleh terlalu panas karena dapat merusak tekstur ikan.

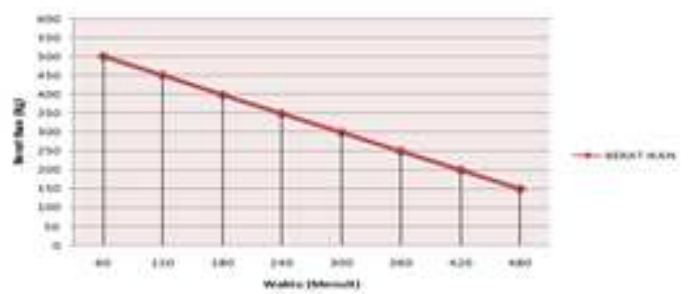

Gambar 5. Penurunan berat ikan selama proses pengasapan

Pengujian Aliran pada Lemari Pengasapan

Untuk mengetahui adanya jenis aliran fluida dilakukan dengan apa yang 
Darianto, Analisa Pengaruh Waktu dan Turbulensi Asap Pada Mesin Pengering ...

disebut dengan biangan reynolds (Re). Dalam mekanika fluida, bilangan Reynolds adalah rasio antara gaya inersia (vsp) terhadap gaya viskos $(\mu)$ yang mengkuantifikasikan hubungan kedua gaya tersebut dengan suatu aliran tertentu.

Besarnya bilangan reynold yang terjadi pada suatu aliran dalam lemari pengasapan dapat menunjukkan apakah profil aliran tersebut laminar atau turbulen. Biasanya angka $\mathrm{Re}<2000$ merupakan batas aliran laminar dan angka lebih besar dari Re $>4000$ dikatakan aliran turbulen. Sedangkan Rd diantara keduanya dinyatakan sebagai aliran transisi.

Dari hasil pengujian alat ukur flow meter $\mathrm{v}=10-6 \mathrm{~m} /$ det.

$$
\operatorname{Re}=\frac{\mathrm{V} \cdot \mathrm{D}}{\mathrm{v}}=\frac{1,5 \cdot 0,083}{10^{-6}}=12450
$$

$$
>4000 \text { ( Aliran turbulent) }
$$

Aliran turbulen adalah aliran fluida yang partikel-partikelnya bergerak secara acak dan tidak stabil dengan kecepatan berflukuasi yang saling interaksi. Akibat dari hal tersebut garis alir antar partikel fluidanya saling berpotongan. Oleh Osborne Reynold digambarkan sebagai bentuk yang tidak stabil yang bercampur dalam waktu yang cepat yang selanjutnya memecah dan menjadi tak terlihat. Pada arus turbulen, massa air bergerak ke atas, kebawah, dan secara lateral berhubungan dengan arus yang umum, memindahkan massa dan momentum. Dengan gerakan tidak beraturan seperti itu, massa atau gumpalan fluida akan mempunyai percepatan menyimpang hanya sedikit persentasinya dari kecepatan rata-rata, meskipun begitu arus turbulen bersifat menentukan arus, sebab turbulen menjaga partikel-partikel dalam suspense, secara konstan, seperti clay dan slit pada sungai dan pasir pada arus turbidit, atau secara berangsur seperti pada kebanyakan butih pasir di sungai, pantai dan bukit pasir.

Turbulensi asap pada lemari pengasapan sangat berpengaruh pada hasil dan lamanya waktu pengasapan. Pada penelitian ini turbulensi asap yang terjadi dalam lemari pengasapan sangat berpengaruh positif karena arah asap yang ada didalam lemari pengasapan sifatnya bolak balik. Jadi, hal ini sangat menguntungkan pada ikan yang berada didalam lemari pengasapan. Dimana ikan akan terkena asap dengan waktu yang lama. Berbeda halnya jika menggunakan aliran laminar atau searah. Asap lebih banyak terbuang ke udara bebas sehingga waktu yang dibutuhkan untuk pengasapan lebih banyak.

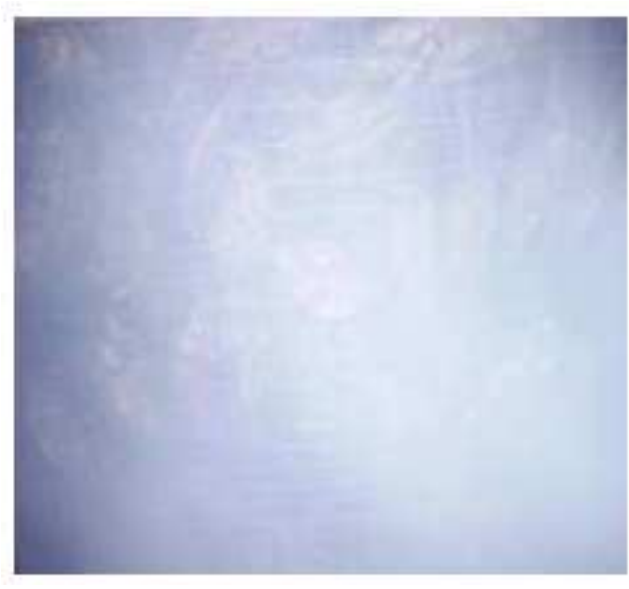

Gambar 6. Kualitas Asap 


\section{Pengujian Kadar Air Pada Ikan Setelah Diasapi}

Laju pengasapan atau kecepatan pengasapan diukur dengan cara menentukan besarnya persentase kadar air ikan selama proses pengasapan. Seiring dengan bertambahnya waktu pengasapan maka berat produk akan semakin berkurang. Cepat lambatnya penurunan kadar air ikan salah satunya dipengaruhi oleh kelembaban udara disekitar produk. Semakin rendah $\mathrm{RH}$, semakin cepat proses dehidrasi. Sementara itu, rendahnya RH dipengaruhi oleh tingginya suhu pada ruangan.

Standar nilai kadar air ikan asap berdasarkan SNI adalah maksimal 60\%. Tingginya kadar air, disebaabkan oleh lama waktu pengasapan yang relative pendek dan suhu pengasapan yang fluktuatif, menyebabkan proses penguapan air menjadi tidak stabil dan menyebabkan nilai kadar air masih tinggi. Terjadinya penurunan kadar air dimungkinkan akibat penguapan dari produk karena suhu udara dan kelembaban lingkungan sekitar.Dalam penelitian ini perlu kita ketahui kandungan air yang ada pada ikan sebelum disapi.

Pada penelitian ini penghitungan kadar air pada ikan lele yang sudah diasapi di uji di Balai riset dan Standarisasi Industri Medan dengan metode SNI 01- 2891 - 1992. Dan dari hasil uji kadar air pada ikan lele yang sudah diasapi dihasilkan 13,4\%. Dengan hasil ini dapat disimpulkan bahwa sirkulasi asap didalam dapur pengasapan yang arahnya turbulen sangat membantu kepada penurunan kadar air yang ada pada ikan.

Tabel 2. Hasil Nilai Kandungan Gizi Ikan Lele Asap Sesuai Uji Test

\begin{tabular}{lcc}
\hline \multicolumn{1}{c}{$\begin{array}{c}\text { Jenis } \\
\text { Kandungan } \\
\text { Gizi }\end{array}$} & Nilai & Satuan \\
\hline Protein & 17,7 & $\%$ \\
Lemak & 4,8 & $\%$ \\
Mineral & 1,2 & $\%$ \\
KH & 0,3 & $\%$ \\
Fosfor & 168 & $\mathrm{mg}$ \\
Abu & 9 & $\mathrm{mg}$ \\
Karbohidrat & $0-1,7$ & $\mathrm{~g}$ \\
Besi & 1,1 & $\mathrm{mg}$ \\
\hline
\end{tabular}

Pendinginan Ikan

Ikan yang sudah selesai diasapi harus dikeluarkan dari alat pengasap untuk selanjutnya didinginkan. Beberapa cara pendingin yang sering dilakukan adalah dengan menggantungkan ikan pada sepotong kayu dan ditutupi dengan kertas untuk menghindari menempelnya kotoran/debu dan serangga pada produk. Pada penelitian ini ikan didinginkan di atas lemari pengasapan dengan ruangan tertutup. Ikan lele yang telah didinginkan diperlihatkan pada gambar 7. 
Darianto, Analisa Pengaruh Waktu dan Turbulensi Asap Pada Mesin Pengering ...

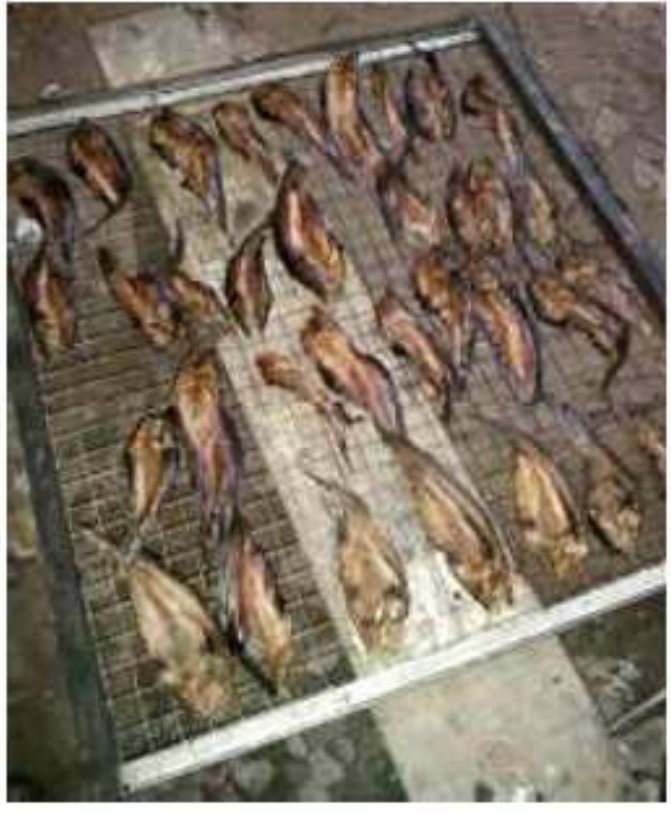

Gambar 7. Hasil pengasapan akhir

\section{KESIMPULAN}

Kesimpulan yang diperoleh dari penelitian Analisa Pengaruh waktu dan turbulensi asap pada mesin pengering ikan lele adalah pengasapan ikan dengan lemari pengasapan dapat diterapkan sebagai metode pengolahan ikan asap dan dapat menghasilkan kualitas ikan asap yang baik secara organoleptik, dan kandungan nutrisi terjaga. Ikan lele memiliki potensi sebagai bahan baku ikan asap yang memiliki proksimat yang tinggi, sehingga mampu memenuhi kebutuhan gizi masyarakat. Waktu yang dibutuhkan untuk menghasilkan hasil pengasapan yang bagus \pm 8 jam.

\section{PENGHARGAAN}

Penghargaan kepada direktur pengusaha ikan sale yang namanya tidak ingin disebutkan yang telah memberikan kesempatan untuk melakukan penelitian ini.

\section{REFERENCES}

[1] Adayah, R. 2007 .Pengolahan dan pengawetan ikan..Bumi Aksara Jakarta.

[2] Anonimous. 2010. Smoke fish production ( enterprise module ). San Juan City.

[3] Badan Standarisasi Nasional, 2006.SNI o14872.1-2006. Es untuk penanganan penanganan ikan I:Spesifikasi. Jakarta.

[4] Badan Standarisasi Nasional. 2000. SNI o14435- 200o. Garam bahan baku untuk industry garam beryodium. Jakarta.

[5] Budiman, M.S. 2004. Teknik penggaraman dan pengeringan.Departemen Pendidikan Nasional. Direktorat Pemasaran Dalam Negeri. 2012. Warta Pasar Ikan dan Kemandirian Pangan. Dirjen PPHP Effendi, M.I. 1979. Biologi Perikanan. Yayasan Pustaka Tama. Yogyakarta. Ishikawa K. 1998. Teknik Penuntun Pengendalian Mutu ( Terjemahan ). Di dalam Muhandri T dan D.

[6] Haruwati, E.S. 2002.Pengolahan Ikan Secara Tradisional Prospek dan Peluang Pengembangan.Jurnal Litbang Pertanian 21 (3).

[7] Hermana, 1991. Iradiasi Pangan Cara Mengawetkan dan Meningkatkan Keamanan Pangan

[8] Hanafi Madura. Makalah Ikan AsapSosis Fermentasi dan Agroindustri Ikan leleNisa, dkk

[9] IR.M.J.Djokosetyardjo : KETEL UAP

[10] IR.Syamsir A. Muin : Pesawat-pesawat konversi energy 1 (KETEL UAP) Kasarisma.Siatem jaminanMutu Industri Pangan. Bogor. IPB Press. Moeljianto R. 1992. 